\title{
A lei complementar em matéria tributária e o imposto sobre serviços de qualquer natureza ${ }^{1}$
}

\author{
Ruth Maria Guerreiro da Fonseca ${ }^{2}$ \\ Marlene Kempfer Bassoli ${ }^{3}$
}

\begin{abstract}
Resumo
O Brasil é uma federação constituída por entes federados titulares de autonomia administrativa, financeira e política nos termos do Art. 18 da CF. Esta forma de organização político-administrativa possibilita uma estrutura normativa com normas nacionais, federais, estaduais e municipais. As normas nacionais devem ser veiculas por meio de lei complementar. Há hierarquia entre normas nacionais e as demais. Sendo assim, os legisladores de normas federais, estaduais e municipais estão vinculados às normas nacionais. No ordenamento jurídico brasileiro as matérias tributárias reservadas às normas nacionais (também denominadas de normas gerais em matéria tributária), estão previstas, especialmente, no Art. 146 da CF. A partir destas considerações a presente pesquisa dedica-se a apurar o alcance das normas tributárias nacionais que tratam sobre o Imposto Sobre Serviços de Qualquer Natureza (ISSQN) de competência municipal. Por meio destas abordagens, enfrentar-se-ão questões jurídicas controversas sobre a materialidade e o local da prestação de serviço tributada por meio do ISSQN. Tais discussões ficam expostas quando da aplicabilidade da metodologia da regra-matriz de incidência fiscal para a construção da norma jurídica tributária do ISSQN tendo em vista a Constituição Federal, a Lei Complementar no 116/2003 e a Lei Municipal.
\end{abstract}

Palavras-Chave: Princípio Federativo; Lei complementar em matéria tributária; Imposto Sobre Serviços de Qualquer Natureza (ISSQN).

\section{Introdução}

O legislador constituinte brasileiro adotou a Federação como modelo para organização político-administrativo do Estado. Cada ente federado é titular de autonomia legislativa, administrativa e política.

Visando possibilitar a efetividade da autonomia financeira, foram designadas atribuições legislativas tributárias, possibilitando a arrecadação de recursos de forma que União, Estados Membros, Distrito Federal e Municípios possuam receitas para atender suas despesas.

Artigo escrito a partir do Trabalho de Conclusão de Graduação (TCC)

Estudante do 5ㅇa ano de graduação do curso de Direito na Universidade Estadual de Londrina

Professora da graduação e pós-graduação Universidade Estadual de Londrina, Pontifícia Universidade Católica de Londrina e da Universidade de Marília-SP. 
Foi conferida aos Municípios a competência para instituir imposto sobre a prestação de serviços de qualquer natureza (ISSQN). Significa titularidade para instituir ou aumentar tal imposto. A incidência da norma municipal, conforme regra federativa deve limitar-se ao seu território.

Mesmo tendo sido a Constituição Federal detalhista quanto à competência tributária para cada ente federado, ao ocorrer interpretação e aplicação da lei municipal do ISSQN conflitos são apontados. Entre eles destaque-se: os limites de lei complementar para tratar deste tributo, especialmente, quando define os serviços sujeitos à tributação bem como o aspecto da territorialidade das normas municipais.

Para enfrentar tais temas há um percurso, ou seja, tratar da natureza jurídica das normas nacionais introduzidas pela lei complementar e seus limites frente às definições constitucionais; tratar da competência tributária municipal garantida na Constituição Federal e os limites do seu exercício.

\section{Federação brasileira: normas nacionais, federais, estaduais e municipais}

A organização político-administrativa federal é um dos suportes do ordenamento constitucional brasileiro, juntamente com a forma de governo republicano. Alcançaram a envergadura constitucional de cláusulas pétreas (Art. 60,§ 4ㅇ CF), portanto, um pacto indissolúvel (Art. 10 CF). Inexistindo o direito de secessão, "sendo inadmissível qualquer pretensão de separação de um Estado-membro, do Distrito Federal ou de qualquer município da Federação" (MORAES, 2003, p. 268).

Determina a Constituição Federal em seu Art. 18 que cada um dos entes tenha autonomia administrativa, financeira e política, garantindo-se a tríplice capacidade de autoorganização administrativa, financeira e auto-governo.

A Lei Maior ao definir o Estado Brasileiro como sendo um Estado Federal repartiu as atribuições administrativas e legislativas entre a União, Estados-membros e Municípios e as atribuições judiciais entre a União e Estados-membros. Para possibilitar o cumprimento destes deveres estabelece as competências tributárias e, conseqüente, arrecadação de receitas para compor o orçamento e fazer frente às despesas.

A União, como congregação das comunidades regionais autônomas, formada pela reunião das partes componentes, corporificado a ordem central do pacto federativo, possui 
atribuições no plano interno e internacional. Nesta hipótese são atribuições que englobam ações típicas da soberania. No plano interno divide-se entre cuidar dos interesses próprios (exercício da autonomia enquanto ente federado) e dos da federação (União, Estado e Municípios). Nesta situação tratando de interesses comuns, de harmonização, para prevenir abalos ao pacto federal. Ao cuidar dos interesses próprios por meio da competência legislativa, no Congresso Nacional, produz normas federais. Ao tratar do interesse dos entes federados, se sobrepõe aos interesses próprios dos entes federativos, por meio do mecanismo de normas nacionais. Do confronto de interesses federativos deverá prevalecer o interesse maior da federação no contexto de preservação do pacto. Este é um argumento que explica a razão pelas quais as normas federais, estaduais e municipais são hierarquicamente inferiores às normas nacionais.

As normas federais serão produzidas pela União e versarão sobre as matérias constitucionalmente previstas para tratar de interesses próprios e não diretamente dos demais entes federados. Têm por destinatários os agentes públicos no cumprimento das atribuições em órgãos que compõem a estrutura da União (federal).

Pode-se considerar que a norma nacional e a federal possuem o mesmo critério espacial e temporal de validade, já que ambas vigoram em todo o território brasileiro e não possuem nenhum critério específico de vigência.

Diferenciar a norma nacional da federal quanto ao aspecto pessoal, pode-se afirmar que têm diferentes destinatários. As normas federais dirigem-se àqueles que têm atribuições constitucionais e legais próprias da União enquanto membro federativo com autonomia. As leis tributárias sobre imposto de renda, empréstimo compulsório e demais tributos federais são exemplos de normas federais produzidas no exercício da autonomia política e financeira da União. As normas nacionais têm por destinatários todos os produtores e aplicadores de normas inaugurais (Legislativo) ou secundárias (poder regulamentar) no plano federal, estadual e municipal. As leis que tratam sobre responsabilidade fiscal, o Código Tributário Nacional, são exemplos de normas nacionais e estão dirigidas à União, aos estados-membros e aos municípios.

Partindo-se para a análise do critério material de validade das normas nacionais e federais, encontra-se uma diferença substancial entre as mesmas. As matérias veiculadas por norma nacional, por vezes têm determinação explícita para que seja veiculado por meio 
de Lei complementar, como é o caso claro do Art. 146 da CF; outras vezes, mesmo sem esta indicação, mas tendo-se em vista o superior interesse federativo de harmonização em questão, deverá ingressar na ordem jurídica no nível de norma nacional, por meio de Lei Complementar, impondo-se a todos os membros federativos, como é o caso previsto no Art. 150 , VI, “c" parte final da CF. Esta interpretação respalda-se no modelo federativo que tem mecanismo de superar os interesses das partes em nome do interesse do todo.

As normas estaduais produzidas na Assembléia Legislativa têm por finalidade disciplinar interesses do Estado. Considerando o sistema de distribuição de competências federativo tem competência residual (Art. 25 CF) uma vez que a federação, no referencial americano, construiu-se a partir dos estados. Dito de outra forma, todas as atribuições de interesse público eram deles tendo renunciado, no mínimo, aquelas típicas de soberania em favor da União. Essas normas terão sua eficácia jurídica no território do Estado-membro, seguindo a regra da territorialidade federal.

As normas municipais produzidas na Câmara de Vereadores versam sobre temas ligados às atribuições definidas nos artigos 29 a 31 da Constituição. Por meio delas cuida dos interesses locais, nos limites do seu território, vivenciando assim as autonomias garantidas pela Lei Maior garantidas, em igualdade, a todos os demais membros federativos.

\section{A lei complementar em matéria tributária}

No exercício das competências legislativas tributárias todos os membros federativos devem obediência à Constituição Federal. A União ao instituir e disciplinar as relações tributárias decorrentes da sua competência deve observar a indicação do veículo introdutor destas normas. Por vezes, para estas normas federais, há indicação de processo legislativo comum (lei ordinária, processo legislativo comum, quorum de maioria simples), por vezes de caminho especial (lei complementar, processo legislativo especial, quórum de maioria qualificada). Para a primeira hipótese tem-se, por exemplo, que os impostos federais previstos no Art. 153 deverão ser introduzidos no ordenamento por meio de lei ordinária (normas federais). Para a segunda hipótese tem-se, por exemplo, o empréstimo compulsório (Art. 148 CF) e a competência residual (Art. 154 CF), que deverão ser veiculados por lei complementar (normas nacionais). 
Interesse especial para estes estudos são as questões em torno do papel da lei complementar enquanto veículo para introduzir norma nacional de conteúdo tributário e que, por força do mecanismo federal já apresentado no tópico 1 acima, se sobrepõe às normas federais, estaduais e municipais.

Além do caminho processual legislativo com quorum especial exigindo maior número de votos dos representantes (maioria daqueles que compõe a casa legislativa) para decidir sobre a norma jurídica a ser introduzida, deve nortear o aspecto material (conteúdo) das normas nacionais o critério de harmonização dos interesses próprios dos membros federativos. Estes devem ser renunciados em favor dos interesses do pacto federal.

Todas as normas jurídicas têm como limite os valores e regras constitucionais. As normas nacionais, apesar de sua hierarquia frente às normas federais, estaduais e municipais, estão limitas quanto aos aspectos materiais e formais aos ditames constitucionais. Sendo assim, o legislador constituinte, ao recorrer à norma nacional em matéria tributária estabeleceu seus conteúdos de modo expresso (Art. 146 CF) e outros decorrem do próprio modelo federal (Art. 150,VI, “c" CF, entre outros).

A força normativa das normas nacionais foi ressalta diante da rígida distribuição das competências tributárias dos entes federados, no exercício da competência residual tributária, em que “a União, por meio de lei complementar, pode alterar o rígido esquema de repartição das competências tributárias das pessoas políticas e, mais do que isto, pode condicionar a validade de suas leis" (CARRAZZA, 2002, p. 790).

O Art. 146 da Lei Maior especifica claramente de que maneira a lei complementar irá legislar em se tratando de matéria tributária. Assim ele prescreve:

Art. 146. Cabe à lei complementar:

I - dispor sobre conflitos de competência, em matéria tributária, entre a União, os Estados, o Distrito Federal e os Municípios; II - regular as limitações constitucionais ao poder de tributar;

III - estabelecer normas gerais em matéria de legislação tributária, especialmente sobre:

a) definição de tributos e de suas espécies, bem como, em relação aos impostos discriminados nesta Constituição, a dos respectivos fatos geradores, bases de cálculo e contribuintes;

b) obrigação, lançamento, crédito, prescrição e decadência tributários;

c) adequado tratamento tributário ao ato cooperativo praticado pelas sociedades cooperativas.

d) definição de tratamento diferenciado e favorecido para as microempresas e para as empresas de pequeno porte, inclusive regimes especiais ou simplificados no 
caso do imposto previsto no art. 155, II, das contribuições previstas no art. 195, I e $\S \S 12$ e 13, e da contribuição a que se refere o art. 239.

Para esta pesquisa destaque-se a norma nacional para dispor sobre conflitos em matéria tributária e regular as limitações constitucionais ao poder de tributar.

Quanto às questões de conflitos de competência em matéria tributária o Prof. Ataliba, ao escrever sobre a lei complementar em matéria tributária, conceitua competência tributária como sendo "a aptidão que as pessoas políticas: União, Estados e Municípios têm para criar e disciplinar tributos"(ATALIBA, 1989, p. 89). Tais definições estão expressas de modo claro e objetivo no texto constitucional, portanto, é preciso avaliar de modo sistêmico qual seria o papel desta norma nacional frente às normas de competência de nível constitucional.

O profo Carrazza (2002, p. 791) afirma:

[...] o art. 146 da Lei Maior deve ser entendido em perfeita harmonia com os dispositivos constitucionais que conferem competências tributárias privativas à União, aos Estados, aos Municípios e ao Distrito Federal, pois a autonomia jurídica destas pessoas políticas envolve princípios constitucionais incontornáveis.

Não se pode considerar que a Constituição afronte um de seus princípios constitucionais com outro artigo de seu texto, por isso imperioso fazerem-se algumas considerações.

O artigo em questão prevê conflitos que em tese não deveriam existir, posto que a própria Constituição delimite as competências de que poderá cada ente legislar em se tratando de matéria tributária. Essas competências são privativas, o que não permite que um invada a esfera legislativa de outro, desrespeitando a Carta Magna.

Profo Ataliba reforça a inexistência de conflitos dizendo que: "se o sistema é esse; rígido e exaustivo não há possibilidade de conflito de competência” (ATALIBA, 1989, p. 48).

A função da lei complementar no âmbito dos conflitos é tentar evitá-los e não dirimi-los. Pode esse tipo de norma reafirmar o que está previsto na Constituição, detalhando o que lá está escrito, apenas reforçando o perfil constitucional de cada tributo. Assim, o limite desta norma nacional são as próprias competências tributárias já demarcadas no texto constitucional. 
Quanto às limitações constitucionais ao poder de tributar, ter-se-ia mais uma vez a questão do afronte aos princípios constitucionais, que no caso seria o fato de que a própria Constituição cria limitações ao poder de tributar, não podendo a lei complementar criar outras limitações ao poder de tributar.

A Lei complementar vem nesse caso regular as limitações ao poder de tributar para "a salvaguarda dos direitos subjetivos dos contribuintes e para prevenir a ocorrência de conflitos de competência entre as pessoas credenciadas a legislar acerca da matéria" (CARRAZZA, 2002, p. 807).

A lei complementar desdobra as normas constitucionais e evita possíveis conflitos entre as entidades tributantes, mas não limita o poder de tributar que está previsto constitucionalmente, apenas regula esse poder, nos casos em que a Constituição permita, não podendo a mesma regular um princípio constitucional, por exemplo.

Cumpre dizer que a lei complementar deve existir de forma harmônica com o previsto no texto constitucional, já que diante das competências tributárias previamente atribuídas aos entes federados, não se poderia contradizê-las sob pena de desrespeito ao princípio federativo.

Desta forma a Carta Magna prevê de forma exaustiva os possíveis conflitos existentes entre os entes tributantes, bem como limita o poder de tributar dos mesmos, podendo a lei complementar simplesmente reafirmar o que já está previsto.

Nos âmbitos federal, estadual municipal a lei complementar também não fixará limites à competência tributária destes membros federados, até porque como já enaltecido as competências tributárias são determinadas pela Constituição e as exceções serão somente as já previstas na Constituição. Normas nacional, federal, estadual ou municipal não poderão diminuir ou ampliar tais direitos.

O Código Tributário Nacional ( CTN, lei $n^{\circ}$. 5.172/66) estabelece normas gerais de aplicação, sendo que essas "normas gerais de direito tributário pertencem ao sistema tributário nacional, subordinando-se ao regime jurídico-constitucional e arrancando dele todas as projeções e efeitos capazes de irradiar" (CARVALHO, 2007, p. 210).

Insta destacar que o CTN foi introduzido no ordenamento jurídico antes mesmo da previsão de lei complementar para a introdução de normas gerais de Direito Tributário. Esta exigência foi determinada a partir da Constituição de 1969 , em seu Art. $18, \S 1^{\circ}$, que dizia 
que as normas gerais de direito tributário somente poderiam ser instituídas por um processo formal específico: a lei complementar.

O Código Tributário Nacional foi recepcionado pelo atual ordenamento no nível de norma nacional, haja vista que seu conteúdo é materialmente complementar, mesmo que formalmente não tenha sido criada através de um processo legislativo especial, pois à época de sua criação não existia tal previsão legislativa.

O CTN é uma lei complementar que contém norma nacional, pois além do que já foi dito a respeito dele ser complementar, enalteça-se sua hierarquia diante das outras normas de conteúdo tributário sejam federais, estaduais ou municipais. Cumprem sua função de harmonização em temas tributários, entre eles, uniformizar normas sobre prescrição e decadência, formas de extinção, suspensão e exclusão do crédito tributário. O limite destas normas são sempre os valores e regras constitucionais tributárias, inclusive aquelas que dizem respeito à estruturação da federação, entre elas, as competências tributárias, a territorialidade tributária, a uniformidade geográfica.

\section{Imposto sobre Serviços de Qualquer Natureza (ISSQN)}

Nos termos do Art. 156, III, da Constituição Federal é garantido aos municípios instituir Imposto sobre os Serviços de Qualquer Natureza (ISSQN), não compreendidos na competência tributária dos estados-membros, tais como aqueles enumerados no Art. 155, II. No final do texto enumerado como Art. 156, III, têm-se as expressões "definidos em lei complementar" que ainda provocam controvérsias acadêmicas e jurisprudenciais.

As questões que foram trazidas à investigação nestes estudos, dizem respeito ao papel desta lei complementar para o ISSQN tendo em vista as matérias que a este instrumento são reservadas no Art. $146 \mathrm{CF}$, entre elas, dirimir conflitos de competências e limitações ao poder de tributar.

A partir deste corte metodológico pode-se afirmar que para os estudos do ISSQN no Brasil, o intérprete deve buscar a Constituição Federal, a Lei Complementar 116/2003 (norma de nível nacional) e a lei do município. Reunindo estes textos do direito positivo, é possível, por meio da metodologia da regra-matriz de incidência fiscal ${ }^{4}$ (CARVALHO, 2007,

\footnotetext{
4 Estes estudos apresentam uma proposta para construir norma jurídica tributária em seu aspecto formal. Parte de estudos da Lógica Jurídica percorre a Teoria Geral do Direito, a Ciência do Direito até alcançar o 
Cap. IX e X), construir norma de incidência fiscal. Esta é norma direito material e tem em sua estrutura a hipótese tributária e a relação jurídica tributária. A hipótese tributária do ISSQN é: a prestar serviços de qualquer natureza e sob regime do Direito Privado, em qualquer ponto do território do município, no momento da prestação do serviço. A relação jurídica tributária indica: sujeito ativo o município, sujeito passivo o prestador de serviços pessoa física ou jurídica, base de cálculo o valor do serviço prestado e alíquota percentual definida em lei municipal.

O Direito Tributário é um Direito de sobreposição. Significa afirmar que busca para interpretação das normas tributárias, em outros ramos do Direito, inclusive de Direito Privado, conceitos, definições, institutos, que para tais normas podem ser aplicados. As determinações normativas para a interpretação das normas tributárias estão nos artigos 107 a 112 do CTN. Entre as restrições sobre interpretação estão aquelas enumeradas no artigo 110, ou seja, podem-se buscar conceitos de outros ramos do Direito, mas sem alterar seu conteúdo e alcance. Sendo assim, é no Direito Civil que se deve buscar a definição do que seja serviço: é uma obrigação de fazer, da qual o esforço para fazê-lo tem que ser em benefício de outra pessoa, em favor de outrem, ele é espécie de qual o trabalho é gênero.

Neste sentido, a prestação de serviços envolve uma relação jurídica entre o prestador de serviços e o tomador de serviços, existindo obrigações para ambas as partes, sendo que a natureza dessas obrigações é determinante para a tributação do serviço.

Importante afirmar que o fato que se pretende tributar deve ter conteúdo econômico, sob pena de desrespeito das exigências da isonomia. Desta maneira, o serviço prestado a si próprio não será passível de tributação se considerado sob esse aspecto, já que não tem conteúdo econômico. A Constituição exige não só pra este, mas para todos os tributos o respeito ao princípio da capacidade contributiva (Art. 145, § $2^{\circ}, \mathrm{CF}$ ).

É tributável pelo ISSQN a prestação de serviço e não o seu consumo, fruição, utilidade ou utilização. Diante dessa afirmação, conclui-se que o prestador de serviço é o destinatário constitucional tributário, já que ele é quem se beneficia da remuneração pela

nível do Direito Positivo para identificar nos textos legais normas jurídicas. Reconhece que a norma jurídica é composta de norma direito material e de direito processual; que cada uma delas tem uma estrutura proposicional de hipotético condicional; para a norma de direito material na posição antecedente descreve um fato de relevância jurídica e a posição conseqüente a relação jurídica; para a norma processual no antecedente há a antijuridicidade e no conseqüente a sanção. Aplicada esta estrutura à norma de incidência fiscal de direito material tem-se no antecedente a hipótese tributária e no conseqüente a relação jurídica tributária. 
prestação. O Município só pode adotar como materialidade de hipótese de incidência do ISSQN o serviço tais como acima descrito.

Nem mesmo o legislador de normas nacionais poderá alterar a definição legal de serviços (obrigação de fazer). Optou este legislador em não definir serviços (já definido pelo Direito Civil), mas apresentar uma relação deles sujeitos á tributação por meio do ISS. Tentou, com esta enumeração, não só identificar quais são tributáveis e, também, evitar possíveis conflitos de competências.

\subsection{Aspectos controversos da materialidade do ISSQN}

As questões que se apresentam quanto à atuação do legislador nacional no aspecto da materialidade do ISS é avaliar se esta lista é necessária como condição para o exercício da competência tributária do Município. A doutrina pátria está dividida em dois grandes grupos: aqueles que interpretam que ela é necessária porque assim determina a Constituição ( parte final do inciso III do Art. 156 CF); outro grupo que advoga que não, pois a competência tributária deriva diretamente da Constituição e fazê-la depender de norma infraconstitucional é restringir o alcance da norma de competência o que não está autorizado na Constituição.

Além desta discussão acadêmica e jurisprudencial, ainda quanto à materialidade, tem a avaliação sobre a possibilidade de norma nacional transformar o que não é serviço em serviço ( Art. 110 CTN). Este tema ressalta, pois no rol trazido por meio da LC 116/2003, vários itens indicam como prestações de serviços sujeitos a essa tributação que não são obrigação de fazer nos termos da lei civil: locação de bens móveis; serviços públicos delegados; cessão de espaço a exemplo dos salões de festas, centro de convenções, estádios e outros. Não sendo serviços não podem compor a materialidade da hipótese tributária do ISSQN. Neste sentido o profo Roque Antonio Carrazza (2002, p. 509) dispõe que:

[...] a lei complementar não pode considerar serviços, para fins de tributação por via do ISSQN, fatos que não os sejam. Isto feriria, dentre outros, o direito subjetivo do contribuinte de só ser tributado pela pessoa política competente e nos estritos termos da Constituição". (CARRAZZA, 2002, p. 509) 
Em se tratando de serviços prestados mediante locação, cessão de uso e congêneres foi declarada a inconstitucionalidade da incidência do ISSQN sobre a locação de bens móveis, por ser essa uma obrigação de dar e não de fazer. (decisão proferida pelo Plenário do Supremo Tribunal Federal no Recurso Extraordinário no 116.121/SP).

Não só a tributação sobre locação de bens móveis foi declarada inconstitucional, como também os serviços semelhantes, conforme expõe Gueiros e Troianelli (2003, p. 117):

\footnotetext{
Tanto essas cessões de direito, locações de bens imóveis para eventos e locações de dutos são semelhantes à locação de bens móveis, que, sob o império da antiga lista de serviços, que não as previa expressamente, os Municípios tentavam - o que era discutível, dada a taxatividade da lista - forçar uma equiparação à locação de bens móveis, expressamente prevista.
}

Qual poderia ser a interpretação para as expressões 'definida em lei complementar', contidas no Art. 156, III, da Constituição Federal? Considerando o disposto no Art. 156 CF seria prevenir conflitos de competência e trazer normas de harmonização sem, no entanto, restringir a autonomia dos municípios por ser esta cláusula pétrea (modelo federal).

Para a função de prevenir conflitos o rol trazido pela LC 116/2003 deve ser interpretado como enumeração exemplificativa e não taxativa. Considerando-se que a competência do Município de tributar independe de lei complementar, não é dado ao legislador complementar estabelecer quais seriam os serviços a serem tributáveis pelo ISSQN. A partir dessa análise, a Lista de Serviços tem a única função de inibir a tributação municipal no caso de serviços de transporte e comunicação transmunicipal ou de serviços confundíveis com operações financeiras ou de atividades de industrialização.

Essa parte da doutrina, que é contrária à taxatividade da Lista de Serviços, elenca os seguintes motivos para demonstrar seu inconformismo com a jurisprudência dominante: a) a taxatividade supõe a superioridade formal da União sobre o Município; b) supõe a existência de hierarquia entre lei complementar e lei ordinária; c) entende que o Município não é autônomo, nem que o Art. 30, da Constituição Federal encerra um magno princípio constitucional; d) reputa como não escrito o preceito do inciso III, do Art. 30 , do texto Constitucional; e) entende que a Constituição tem preceitos que atribuem e outros que depois retiram o que foi atribuído; invalidando outorgas por ela mesma concedidas; f) nega coerência e lógica ao sistema constitucional; g) admite que a Constituição é flexível e pode 
ser alterada por lei complementar; h) entende que as competências tributárias constitucionalmente previstas, podem ser ampliadas, reduzidas e até mesmo anuladas pela lei complementar; i) admite que o Congresso pode suprimir (por omissão) competência do Município para criar o ISSQN.

Outra corrente doutrinária sustenta que no regime constitucional vigente, se o serviço não estiver previsto em lei complementar municipal, jamais poderá servir de hipótese de incidência do ISSQN, por impedimento constitucional. Sustenta que a lista é taxativa.

Problemas surgem com relação à questão da taxatividade da lista estipulada em lei complementar. Cita-se a questão dos serviços relacionados ao setor bancário ou financeiro, inclusive aqueles prestados por instituições financeiras autorizados a funcionar pela União ou por quem de direito; a questão dos serviços de cuidados pessoais, estética, atividades físicas e a dos serviços prestados mediante locação, cessão de uso e congêneres.

Quanto às instituições financeiras e os bancos prestam diversos serviços passíveis de tributação pelo ISSQN, sendo que estava previsto no Decreto-lei 406/68, que foi alterado pela Lei complementar 116/03 a lista dos serviços passíveis de tributação. Esta lista contém os principais serviços prestados pelos bancos e instituições financeiras, sendo que na maioria deles existem subitens e a expressão "e congêneres". Neste estariam incluídos espécies do gênero serviço bancário?

Os bancos e instituições financeiras muitas vezes atribuírem, para fins contábeis, denominações próprias aos serviços prestados. Estes "títulos" por vezes não coincidem com as denominações da lista do ISSQN. Sendo assim defendem não estarem sujeitos a esta tributação por não constar expressamente no rol de serviços da lei. Na outra ponta destas argumentações, estão os municípios defendendo que na expressão "congêneres" poderão ser incluídos tais serviços, desde que não tributados pela União ou estados-membros, e que se tratem de obrigação de fazer.

Com a edição desta lei foram acrescentados subitens como espécies do gênero, alguns que detalham o serviço e outros que alargam a hipótese de incidência do tributo. 0 problema desta subtemização será de que a lista pode não acompanhar o desenvolvimento de novos serviços. Poderá acontecer que um tipo de prestação de serviço preencher todos os requisitos da hipótese de incidência do ISSQN não ser tributável pelo simples fato de não 
conter na lista de serviços anexa à lei. Ofende-se, assim, o valor constitucional da igualdade tributária no qual se fundamente a regra da capacidade contributiva.

Antes mesmo de estar ou não incluso o serviço na lista de serviços, que é considerada pela maioria da doutrina como sendo taxativa, tem-se que verificar se o serviço prestado encaixa-se nos parâmetros ditados constitucionalmente como necessários à tributação pelo ISSQN.

A própria Constituição Federal determinou a regra matriz de incidência do ISSQN, estabelecendo critérios (material, espacial, temporal) que se preenchidos devem ser os serviços tributáveis pelo ISSQN.

A questão deve girar em torno da hipótese de incidência do ISSQN, sob pena de inconstitucionalidade. Se o Texto Maior prevê quais serão os serviços prestados passíveis de tributação pelo município, não podem nem este e nem os prestadores de serviço fugir dessa regra, para não desrespeitarem a Lei Maior de nosso ordenamento jurídico.

Neste sentido, Chiesa (2003, p. 53) faz as seguintes considerações:

\begin{abstract}
Defendemos que lei infraconstitucional, ainda que seja a lei complementar, não pode limitar a atuação do legislador municipal, pois isso implicaria a violação ao princípio da autonomia dos Municípios. Admitir que a lei complementar possa apontar os serviços que poderão ser tributados por meio de ISS, é transferir para o Congresso Nacional o poder de definir, por meio de lei infraconstitucional, o campo de atuação dos Municípios no tocante a esse imposto, amesquinhando a autonomia das unidades municipais.
\end{abstract}

Importante considerar que diante da discussão da taxatividade ou não da lista de serviços prevista em lei complementar, deve-se respeitar a autonomia dos municípios para instituir imposto sobre a prestação de serviços.

O modelo federativo garante ao município a autonomia e, nos termos, constitucionais atribuiu-se competência para instituir o ISSQN. Para tanto, importa se o serviço prestado encaixa-se na hipótese de incidência deste tributo e não se ele está incluso na lista, já que ela é "sugestiva e, por isso mesmo, perfeitamente dispensável, tanto pelo legislador municipal quanto pelo juiz e pelo administrador público" (CARRAZZA, 2002, p. 842).

Neste sentido, já existe entendimento jurisprudencial a respeito: 
E M E N T A: IMPOSTO SOBRE SERVIÇOS (ISS) - LOCAÇÃO DE VEÍCULO AUTOMOTOR - INADMISSIBILIDADE, EM TAL HIPÓTESE, DA INCIDÊNCIA DESSE TRIBUTO MUNICIPAL - DISTINÇÃO NECESSÁRIA ENTRE LOCAÇÃO DE BENS MÓVEIS (OBRIGAÇÃO DE DAR OU DE ENTREGAR) E PRESTAÇÃO DE SERVIÇOS (OBRIGAÇÃO DE FAZER) - IMPOSSIBILIDADE DE A LEGISLAÇÃO TRIBUTÁRIA MUNICIPAL ALTERAR A DEFINIÇÃO E O ALCANCE DE CONCEITOS DE DIREITO PRIVADO (CTN, ART. 110) INCONSTITUCIONALIDADE DO ITEM 79 DA ANTIGA LISTA DE SERVIÇOS ANEXA AO DECRETO-LEI № 406/68 - PRECEDENTES DO SUPREMO TRIBUNAL FEDERAL RECURSO IMPROVIDO. - Não se revela tributável, mediante ISS, a locação de veículos automotores (que consubstancia obrigação de dar ou de entregar), eis que esse tributo municipal somente pode incidir sobre obrigações de fazer, a cuja matriz conceitual não se ajusta a figura contratual da locação de bens móveis. Precedentes (STF). Doutrina (RE-AgR 446003 / PR - PARANÁ AG.REG.NO RECURSO EXTRAORDINÁRIO Relator(a): Min. CELSO DE MELLO Julgamento: 30/05/2006 Órgão Julgador: Segunda Turma)

\subsection{Aspectos controversos quanto ao local da prestação de serviços}

Para a configuração da hipótese de incidência do ISSQN se faz necessária a identificação também do critério espacial definido em lei. Neste sentido, se considerada a competência do município para instituir imposto sobre serviços de qualquer natureza, desde que prestados por pessoa física ou jurídica, sob o regime privado, com conteúdo econômico, importante destacar em que espaço essa tributação será permitida.

O aspecto espacial delimita a competência do município que poderá cobrar tributos somente sobre os eventos ocorridos nos precisos e estritos limites de seu território. Isso quer dizer que qualquer exigência feita fora desse âmbito não será considerada válida por fugir à sua competência constitucionalmente definida. É a regra geral federativa da territorialidade.

O aspecto espacial do ISSQN é caracterizado por Barreto (2003, p. 259-260):

O aspecto espacial desse imposto comporta duas vertentes. Uma, genérica, que se confunde com o próprio âmbito de validade da Lei o qual não pode ser ampliado por iniciativa do legislador municipal, embora possa ser reduzido. A segunda, específica, diz respeito ao compromisso que a lei estabelece entre o fato imponível e uma determinada circunstância de lugar.

Levando-se em consideração que o ISSQN deve ser cobrado dentro dos limites geográficos do município onde ocorreu a prestação de serviços, teoricamente não existiriam conflitos relativos ao aspecto espacial desse imposto.

O ISSQN por incidir sobre a prestação de serviço, que é uma obrigação de fazer, podendo ser concluída após várias etapas ou até mesmo podendo ser realizada por um 60

ReVista de Direito Público, Londrina, V. 2, N. 3, P. 47-64, SET./DEZ. 2007. 
prestador residente em local diverso do da prestação, pode muitas vezes extravasar o âmbito do Município.

Com o advento da Lei Complementar no. 116/2003, a situação ficou definida da seguinte forma: o serviço considera-se prestado e o imposto devido no local do estabelecimento prestador ou, na falta sua falta, no local do domicílio do prestador, exceto nas hipóteses previstas nos incisos I a XXII, do Art. 3ำ, quando o imposto será devido, por exemplo, no local do estabelecimento do tomador ou intermediário do serviço ou, na falta

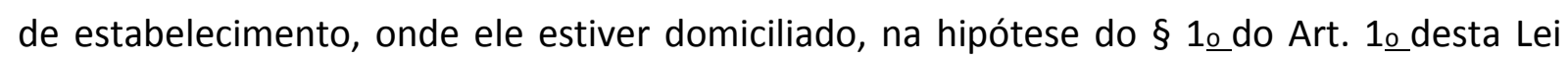
Complementar; da execução da obra, no caso dos serviços descritos no subitem 7.02 e 7.19 da lista de serviços. (Art.3으, LC 116/03).

A nova lei considerou o estabelecimento prestador o local onde o contribuinte desenvolva a atividade de prestar serviços, de modo permanente ou temporário, e que configure unidade econômica ou profissional, sendo irrelevantes para caracterizá-lo as denominações de sede, filial, agência, posto de atendimento, sucursal, escritório de representação ou contato ou quaisquer outras que venham a ser utilizadas (Art. 4ㅇ da LC $116 / 03)$

A referida lei no intuito de dirimir possíveis conflitos de competência entre os municípios definiu o que seria estabelecimento prestador. A lei acabou por trazer mais conflitos, visto que prevê como critério espacial da hipótese de incidência deste imposto o domicílio do prestador, local onde os serviços podem não ter sido prestados.

Há jurisprudência nesse sentido:

\begin{abstract}
O Supremo Tribunal Federal, no julgamento do RE 99.397-5-ES, por sua 2a Turma (RT 579/249 e RTJ 106/865), assim decidiu sobre a questão do estabelecimento prestador: "Com efeito, a existência de estabelecimento em Governador Valadares não desautoriza a comprovação de outro nesta Capital, onde a prestação de serviços de limpeza está plenamente comprovada. E quanto a estabelecimento para efeito de pagamento de imposto, vale a lição de Hely Lopes Meirelles. Note-se que mesmo outras atividades como a de venda de bilhetes de loteria e circulação nacional, estão compreendidas na esfera de tributação do ISS. Por que, então, isentar-se os que são prestados pela apelante, que aqui exerce as sua $s$ atividades, até ostensivamente, com escritórios, mediante contrato e até utilizando-se de próprios daqueles a quem presta tais serviços? Tenho como válidas as cobranças.
\end{abstract}

A Carta Magna já traz em seu texto o critério espacial do ISSQN quando diz que o local de prestação é o do município onde se conclui, onde se consuma o fato tributário, onde 
se produzem os resultados da prestação de serviço. Assim, deve-se o ISSQN onde efetuar-se a prestação do serviço.

Neste caso a lei infraconstitucional trouxe insegurança jurídica quando tratou de especificar onde seria devido o ISSQN, sendo que já existe essa previsão constitucional. E mais, o princípio federativo da territorialidade foi desrespeitado se considerado que pode acontecer de um serviço ser concluído num unicípio e tributado em um diverso, por levar-se em conta o fato do local do estabelecimento prestador e não onde o serviço é efetivado.

O doutrinador Mello $(2003$, p.230) trata da questão da territorialidade em face da LC 116/03 com ressalva:

A questão pertinente à territorialidade (local da efetiva prestação dos serviços), de certa forma, acabou sendo prejudicada. Realmente, a situação excepcional (serviços de construção civil, previstos no DL 406/68) não mais se contém na nova legislação, acrescido do fato de que o estabelecimento prestador nem sempre se encontra no Município onde o serviço é realizado.

A lei complementar 116/2003 afronta o princípio da territorialidade da tributação decorrente das regras federativas da territorialidade. O local da prestação de serviço é o único que deve ser considerado para a hipótese tributária do ISSQN. Resta evidente que um dos objetivos principais definidos pela Constituição Federal para a lei complementar não foi atingido, uma vez que nem ao menos evitou possíveis conflitos de competência.

\section{Conclusão}

O município como ente integrante da Federação brasileira possui competência tributária. Por meio de seu exercício viabiliza sua autonomia financeira. Os limites para esta atribuição são os constitucionais e aqueles enumerados em norma nacional veiculada por lei complementar.

Em matéria tributária, tem-se no ordenamento jurídico o Código Tributário Nacional, que estabeleceu certos requisitos para a cobrança dos tributos previsto na Lei Maior, destacando-se no presente estudo o Imposto Sobre Serviços de Qualquer Natureza ISSQN, de competência municipal, do qual tratou igualmente a lei complementar 116/2003. 
Analisando os textos de direito que tratam do ISSQN questões controversas podem ser apontadas, tais como o da lista de serviços tributáveis e da delimitação do local onde se considera prestado o serviço para a tributação pelo município.

A lei complementar, mesmo de nível nacional, não pode afrontar o texto constitucional sob pena de invalidade. É possível concluir: que a lista de serviços anexa à LC 116/03 não deve ser interpretada como taxativa por ofender a autonomia dos municípios e restringir a ampla competência tributária municipal garantida em nível constitucional; e que, por simples interpretação do modelo federativo, em sua regra de territorialidade, a definição do local em que se considera prestado o serviço tributável deve ser onde ele efetivamente ocorreu, não importando o local do estabelecimento prestador.

Conclui-se que a edição da LC 116/03, ao contrário do que se esperava, não gerou aos seus destinatários (municípios e prestadores de serviço sujeito ao ISSQN) segurança jurídica. Trouxe dúvidas quanto aos critérios material e espacial da hipótese tributária da norma de incidência desse imposto, por afrontar as regras constitucionais da garantia da competência tributária municipal derivada diretamente da Constituição e da regra da territorialidade federativa, sendo esta, inclusive, cláusula pétrea.

\section{Referências}

ATALIBA, Geraldo. Lei complementar em matéria tributária. Revista de Direito Tributário, São Paulo, n. 48, 1989.

BARRETO, Aires. ISS na Constituição e na lei. São Paulo: Dialética, 2003.

BRASIL. Supremo Tribunal Federal. RE-AGR 446003 / PR - Paraná Ag. Reg.no recurso extraordinário relator(a): min. Celso de Mello julgamento: 30/05/2006 órgão julgador: segunda turma. Publicação DJ 04-08-2006 PP-00071 Ement Vol-02240-06 PP-01094. Disponível em: <www.stf.gov.br>. Acesso em: 28 jun 2007. $106 / 865$.

. Supremo Tribunal Federal.RE 99.397-5-ES, por sua 2a Turma. Lex: RT 579/249 e RTJ

CARRAZZA, Roque Antônio. Curso de direito constitucional tributário. 18. ed. São Paulo: Malheiros, 2002.

CARVALHO, Paulo de Barros. Curso de direito tributário. 18. ed. São Paulo: Saraiva, 2007. 
CHIESA, Clélio. O imposto sobre serviços de qualquer natureza e aspectos relevantes da lei complementar no 116/03. In: ROCHA, Valdir de Oliveira (Coord.). O ISS e a LC 116. São Paulo: Dialética, 2003.

GUEIROS, Juliana; TROIANELLI, Gabriel Lacerda. O ISS e a lei complementar no 116/03: aspectos polêmicos da lista de serviços. In: ROCHA, Valdir de Oliveira (Coord.). O ISS e a LC 116. São Paulo: Dialética, 2003.

MELLO, José Eduardo Soares de. Incidência do ISS no local de estabelecimento prestador. In: ROCHA, Valdir de Oliveira. O ISS e a LC 116. São Paulo: Dialética, 2003.

MORAES, Alexandre de. Direito constitucional. 14. ed. São Paulo: Atlas, 2003. 